6. Пометун О. Енциклопедія інтерактивного навчання. Бібліотека журналу Історія і суспільствознавство в школах України: теорія та методика навчання. 2014. № 5-6(8). 95 с.

DOI https://doi.org/10.30525/978-9934-26-004-9-35

\title{
СТАНОВЛЕННЯ ДИТЯЧОГО ХОРОВОГО ПРОФЕСІОНАЛІЗМУ В УКРАЇНІ У ДЗЕРКАЛІ ТВОРЧОЇ ПОСТАТІ ЕЛЕОНОРИ ВИНОГРАДОВОЇ
}

\author{
Щербій C. $O$. \\ аспірант \\ Навчально-наукового інституту мистецтв \\ ДВНЗ «Прикарпатський національний університет \\ імені Василя Стефаника» \\ м. Івано-Франківськ, Украӥна
}

Історія особистостей, які своєю творчістю й життям утверджують одвічно духовні цінності, творить українську хорову культуру. В плані концепції потенціалу в соціальній та індивідуальній життедіяльності показовою $є$ постать української диригентки, педагога і громадського діяча Е. Виноградової, для якої мистецька діяльність була невід'ємною частиною життєвого процесу.

Творча постать Елеонори Олексіївни (1931 - 2003) вирізняється мистецькою неповторністю і високою духовністю. Митець і педагог, заслужений діяч мистецтв України, професор Національної музичної академії України ім. П. Чайковського Елеонора Виноградова своїм творчим життям сприяла розвитку українського дитячого хорового співу, класичні традиції якого вона плекала понад три десятиліття. На всіх етапах довгої мистецької дороги вона послідовно і цілеспрямовано відстоювала високий професіоналізм і відданість своєму покликанню. Важливою умовою успішної творчості було сприйняття нових ідей, здатність знаходити і порушувати проблеми, критичність і сміливість, завзятість та наполегливість. Ї̈і творче мислення постійно стимулювало процес - створення чогось нового на різних етапах (постановка нової проблеми, відшукання нових способів іiї розв'язання, отримання нового результату) [2]. 
Народилася 16 листопада 1931 року у м. Грозний. Любов до хорового співу прийшла ще у ранньому дитинстві через безпосередню участь у хорах і багатий слуховий досвід. Мати Елеонори Олексіївни - Віра Романівна мала чудовий голос і музичний слух, а найбільше любила співати у хорі. Батько - Олексій Миколайович був військовим і сім'я часто переїздила 3 одного міста в інше (Грозний, Сухумі, Тбілісі, Магаданська область). У десятилітньому віці (1941) Елеонора Олексіївна вперше почула хорові твори Миколи Леонтовича у містечку Сусумал на Колимі (800 км від Магадану). Керівником хорового колективу був українець і хор співав багато українських пісень. Крім співу, в домі Виноградових жила також стихія літератури. Батько чудово читав вірші, був прекрасним лектором, володів виразним мистецьким талантом. Ці риси по спадковості передалися і дочці. Постійні переїзди батьків не дозволили закінчити музичної школи й відповідно вступати до музичного закладу. Основними факторами у формуванні особистості митця стали її вроджені індивідуальні здібності, сімейні традиції, а також відповідне соціокультурне середовище.

У 1949 році - вона студентка Московського текстильного інституту та активна учасниця хорового колективу під керівництвом О. І. Певзнера (тоді студент Московської консерваторії, який згодом став відомим хоровим диригентом). Ї̈і чудові голосові дані й музикальність викликали у нього захоплення. За його порадою Елеонора Олексіївна вступила до музичного училища ім. Гнєсіних на диригентсько-хоровий відділ (кл. викл. В. І. Краснощокова). Як згадувала Е. Виноградова, в мистецькому житті тоді вона пережила сильне враження, коли московський хор інституту та училища ім. Гнєсіних виконував «Реквієм» В. А. Моцарта. «Монолітне звучання хору, тембри оркестру, - все захоплювало до глибини серця, - зізнавалася Елеонора Олексіївна, а коли ми заспівали «Lacrymosa», сльози градом покотилися мені по обличчю. Я вперше зазнала такого сильного переживання і цей стан пам'ятаю все життя».

Наступним етапом на шляху осягнення Елеонорою Виноградовою таїни хорового мистецтва став київський період іiї життя. 31965 року, по закінченню Київської консерваторії ім. П. Чайковського в класі Е. Скрипчинської, вона працює керівником хору музично-педагогічного факультету. На той час у неї було троє дітей - два сини та наймолодша донька. Чоловік Володимир Ілліч Суржа на той час працював диригентом-хормейстером Державного українського народного хору (тепер Національний заслужений академічний український народний хор імені Григорія Верьовки). Із цим колективом гастролював по Україні, 
республіках колишнього СРСР, у Бельгії, Канаді, Мексиці, Німеччині, Північній Кореї, Франції, Чехословаччині.

Саме у цей час очолити студентський хор диригентсько-хорового факультету запросили Павла Івановича Муравського. На Елеонору Олексіївну справила сильне враження його підхід до роботи 3 хором: «Звук хору, інтонація, тембри - все було нове, сповнене дивовижної краси та природности. Лише у Муравського я зрозуміла як народжується краса музики від звуку до стилю.» [1, ст. 609]. Вона акцентувала увагу на високий талант маестро та цілеспрямовану послідовну роботу, що створювало сприятливі умови для утвердження та розвитку хорового виконавства.

Наділена від природи ясним талантом і працелюбністю, збагачена досвідом навчання у Москві та Києві, Елеонора Виноградова починає торувати свою дорогу до верховин хорового мистецтва. Адже, ще у Москві слухаючи хор хлопчиків з Лейпцига, вона заповіла собі створити у майбутньому капелу хлопчиків та юнаків.

У 1966-1983 роках - засновник і художній керівник хору хлопчиків та юнаків «Дзвіночок». Цей колектив уперше в Україні озвучив заборонені на той час хорові партитури Д. Бортнянського та М. Березовського. Він став дипломантом Міжнародного фестивалю дитячих хорів, а Елеонора Олексіївна - лауреатом конкурсу. Хор «Дзвіночок» належить до найбільш визначних хорових колективів України, чиє мистецтво залишило найбільш помітний слід в історії хорової культури України [4, ст. 43]. За iї ініціативи та сприяння при чоловічій капелі ім. Л. Ревуцького створено хор хлопчиків і юнаків для збереження спадковості хорової традиції.

У 1975-1990 роках - засновник центру диригентів-хормейстерів та композиторів «Тоніка», діяльність якого активізувала процес відродження дитячого хорового співу та зацікавленість питаннями дитячого виконавства в Україні. Значну роль клуб відіграв в обміні мистецьким досвідом між сусідніми країнами. На іiі запрошення приїжджало багато хорових колетивів із союзних республік, зокрема хор хлопчиків ССМС ім. Е. Дарзиня (1982, худ. кер. Я. Еренштрейтс, конц. Р. Паулс) та інші [5, ст. 238]. Співпраця з такими композиторами як К. Мясков, Л. Дичко, Б. Фільц, В. Кирейко, Ж. Колодуб, В. Шаповаленко та іншими, сприяла розширенню жанрово-стильового діапазону репертуару дитячих хорових колективів.

У 1983-1986 роках Е. Виноградова художній керівник та головний диригент дитячого хорового колективу «Любисток» при Київській 
консерваторії ім. П. Чайковського. Хор став Лауреатом конкурсу ім. М. Леонтовича.

У 1986-1997 роках - художній кервник та головний диригент дитчого хору хлопчиків та юнаків Києвської спеціалізованої музичної школи ім. М. Лисенка. Гастрольні поїздки хору під орудою Е. О. Виноградової майже в усі європейські країни (Франція, Бельгія, Німеччина, Норвегія, Угорщина, Іспанія, Італія та ін.) утвердили авторитет цього колективу як високопрофесійного.

У 1997-2003 роках - художній кервник та головний диригент дитячого хору «Кантус» Київської музичної школи № 5. Цей хор в Іспанії вимоглива преса назвала хор кращим дитячим хоровим колективом у світі 1999 року.

Підсумовуючи розгляд життєтворчості Е. Виноградової, можемо констатувати те що важливими факторами в формуванні особистості мисткині стали іiі вроджені індивідуальні здібності, які досить рано проявилися i отримали належний початковий розвиток в творчій атмосфері інтелігентної родини. Подальшому формуванню світоглядних орієнтирів, життєвих та мистецьких принципів сприяли совітні, культурно-мистецькі традиції навколишнього середовища.

Співпрацюючи тривалий час 3 представниками хорової культури, зокрема київської традиції, перейнявши від них чималий багаж хормейстерського досвіду, Е. Виноградова стала ключовою фігурою в процесі професіоналізації дитячого хорового виконавства України другої половини XX століття. В результаті іiі багаторічної диригентсько педагогічної діяльності сформувалася певна звукова парадигма хорової звучності, яку наслідувало декілька поколінь вихованих нею диригентівхормейстерів, виконавців-інтерпретаторів, формуючи виконавські манери багатьох хорових колективів.

\section{Література:}

1. Бенч О. Павло Муравський. Феномен одного життя. Дніпро, 2002. ст. 664.

2. Селезнева Н. Професіоналізм хормейстера. Психологічний та культурно-історичний аспекти : автореф. дис... канд. мистецтвознавства: 17.00.03; Одеська держ. музична академія ім. А.В. Нежданової. Одеса, 2004. $16 \mathrm{c}$.

3. Рожок В. Музика i сучасність: монографічні дослідження, науково-популярні критичні та публіцистичні твори. Київ: Пошуковавидавниче агентство «Книга пам’яті України», 2003. 220 ст. 
4. Українсько-латвійські музичні зв'язки як вияв інтеграційних процесів у європейському культурному просторі. VII Міжнародний конгрес українців. Збірник наукових статей. Мистецтвознавство. Культурологія \Г. Скрипник; НАНУ; ІМФЕ ім. М. Т. Рильського. Київ. 2008. $320 \mathrm{c}$.

DOI https://doi.org/10.30525/978-9934-26-004-9-36

\title{
ТРАДИЦЙНЕ ВЕСІЛЛЯ УКРАЇНЦІВ ЯК ЕТНОКУЛЬТУРНИЙ ФЕНОМЕН УКЛАДАННЯ «МИРУ» МІЖ «ЧУЖИМИ» СВІТАМИ
}

\author{
Щербіна I. B. \\ кандидат мистеитвознавства, доцент, \\ дочент кафедри музикознавства та вокально-хорового мистецтвва \\ Уманського державного педагогічного університету \\ імені Павла Тичини \\ м. Умань, Черкаська область, Украӥна
}

Традиційна соціально-юридична та релігійно-магічна система людського соціуму формувалася в умовах боротьби особи за існування як біологічної і водночас соціальної істоти - табу забезпечували порядок у громаді, а обрядові дії підтримували рівновагу між «чужими» світами засобом виконання ритуалів, головна функція яких - укласти максимально вигідний для обох сторін договір і тим самим уникнути ворожнечі між «чужими» світами та унеможливить проникнення хаосу в «свій» світ. Досягти успіху в цій справі можливо лише за умов компетентного укладання угоди, яка враховує можливості, потреби і закони як «свого» світу, так і «чужого» оскільки саме сув'язь ворожнечі й любові, за визначенням О. Потебні, створюють неосяжний світ взаємозв'язку причин та наслідків, а «одруження є не що інше, як символ боротьби життя й смерті. Саме весільне застілля є символом боротьби, де п'яна людина вважається мертвою, а весілля в цілому - миром» [1, с. 11-12].

Досліджуючи весільну обрядовість слов'ян, М. Сумцов дійшов висновку, що всі народні гуляння первинно були складовими язичницького свята «Веселія», присвяченого служінню богу Сонця Дажбогу, яке врівноважувало світовий порядок: у ньому брали активну участь боги та люди, які намагалися вплинути на космологічні явища $\mathrm{i}$ тим самим одержати багатий врожай і забезпечити власний добробут. 